\title{
Drugs Abuse among Youth in Maiduguri, Borno State, Nigeria
}

\author{
${ }^{1}$ Baba Gana Alimi \\ Department of Social Services, Ramat Polytechnic \\ Maiduguri \\ ${ }^{3}$ Ahmed Garba \\ Department of General Studies, Taraba State College of \\ Agriculture, Jalingo
}

\begin{abstract}
This paper examines the factors motivating youths to engage in drug abuse in Maiduguri Metropolis of Borno State. This paper also identified the consequences of drug abuse on human health. It also gives some strategies and recommendations as the best path to tackle the challenges of drug abuse in our society. This paper reviewed several related literatures and theoretical perspectives to understand the root causes that motivating the youths to abuse drugs in our community, despite government efforts to curb the menace to the minimum level. Substance abuse has been pandemic confronting Nigerians. The phenomenon of drugs abuse has tremendously increased in the recent years. It is fact that the drug abuse and it related antisocial behaviour has consumes the entire population of society to the extent that it requires collective to address the situation, hence the youths are the future leader. A descriptive survey research design and focus group discussion was used to generate data required from the respondents (drug abusers). A statistical method of simple frequency distribution and percentages and chi-square were applied to distinguish the respondent' $s$ responses on the phenomena under study. The study findings revealed that peer group, joblessness, frustration, poverty, broken home, poor socialization, access to the drugs etc. are the factors motivating the youth' $s$ minds to involve in drug abuse. A sample of 150 respondents were used, 10 from each ward out of the 15 wards of Maiduguri Metropolitan of Borno State. Suggestions were made to tackle the situation.
\end{abstract}

Keyword:- Drug, Abuse, Youth.

\section{INTRODUCTION}

Drug abuse has been a pandemic to all concern stakeholders, government, researchers and society as a whole. It has greatly affected the social, economic and political progress and development of Nigeria. The substance addiction continuous to be principal source of establishing anti social behaviour associated with health hazards among youth in society. Besides, the dangers or consequences associated with it, youth continuously taking the drugs at their detriment (Mamman, H. et al., 2015: 5). Drug abuse is rapidly growing and affecting almost every country in the world. The unprecedented increased in drug

\author{
${ }^{2}$ Bintu Kachalla Galadima \\ Department of Sociology and Anthropology \\ University of Maiduguri \\ ${ }^{4}$ Hassan Suleiman \\ Department of Social Services, Ramat Polytechnic \\ Maiduguri
}

abuse has created a serious problems ranging from formation of illegal group to cause havoc, increase in violence, cultism and creation of related group vulnerable of committing crime and undermining the progress and development of society.

The majority of the youth population nowadays abusing substances abuses disorderly to the extent of compromising their health status and future as well. (Johnson, O' Malley, and Bachman, 2003). A vast population of youths abusing drugs for pleasure and continuous intake of the substances could lead to undesirable consequences, such as organs damage, complicated illness, premature death, traffic accident, family breakdown etc. (Bolaji, K. 2018: 3). Similarly, Eric, P. (2017) opined that a community mostly made up youth who are substance addicts are a weak society, hence their strength has been invested and waste in the activity of abusing drugs. The implications of substance addiction are myriad and range from large numbers of untimely deaths such as suicides, road accidents, violence, crimes, laziness and subsequent impoverishment. In view of that homes are broken, dreams are shattered and potential manpower is wasted as drug abusers struggle to sustain their habits. They therefore, become burdens to themselves, families, the society, and the state at large (Eric, P. 2017). Drugs abuse is among the social problems that are affecting Nigeria economy which in turn is affecting its development. The abuse of substances is so pervasive to the extent that it becomes a serious development challenge and continued to undermine the individual efforts and render them meaningless (Abang, 2006; NDLEA, 2008; Magaji, A.A. 2018). Other reports indicate that a worker under the influence of drugs abuse could affect his/her potentiality, productivity, output, income and service delivery and more likely commit antisocial behaviour and leading to dismissal (INCB, Report, 2013). In related development, Mamman, H.M. et al., (2014: 5) added that drug abuse among Nigerian youths has been a trait of a morally bankrupt, corrupt and wasted generation and loss of our societal values and ideals. The situation is now appears to be such that no one can ignore of what is happening (Abudu, 2008). Drugs abuses threaten the peaceful atmosphere of every society. (Giade, 2011; Mamman, H. et al., 2014). 
The alarming rate of abuse of drugs by youths in Maiduguri Metropolis has been a major concern for general public, government, parents, community and other concern stakeholders to demonstrate efforts to tackle the menace of abusing substances among our youths. Drug abuse has been a pandemic that claims the lives of many youth irrespective of any demographic affiliations. (Eric, P. 2017). Drug abuse has been described as a global calamity like corona virus spreading relentlessly and crippling the world economy. (UNODC, 2017). The use and abuse among youth is too worrisome phenomena threatening the lives of many youth in Nigeria. (NDLEA, 1997).

It is evident from the reports of ICIR (2016) that Borno State Government has raised alarm over the addendum rate of drug abuse among its citizens especially in the internally displaced persons (IDP' s Camps) as well as in communities liberated from Boko Haram. The State Government after careful observation is considering the declaration of State of Emergency on illicit drug use to stem the menace of the drug abuse among its citizens (ICIR, 2016). According to premium times (2016) despite of these challenges, the NDLEA, Borno Command was able to recover more than 20 tonnes of various assorted illicit drugs. On the other hand, significant arrests of drugs barons, consumers and other traffickers were made in October, 2016 and 2017. The NDLEA Command also added that the drugs abuse amongst youths in Maiduguri was becoming alarming that something needs to be done to minimize the phenomena (Premium times, 2016). Similarly, Omirin, (2018) reported that a high proportion of women and youths across the city, including students of tertiary institutions, married women, unemployed girls, workers among others were considered hooked on drugs (Omirin, O. 2018). It was also clearly stated in the reports of Utomi (2019) that the consumption of hard drugs in amounts and ways not authorized by medical professionals has becomes high but a silent reality that Nigerians should worry about. Although, drug abuse is cuts across all social strata. Statistics made it clear that the youths, mostly males with a sprinkle of females, are the real culprits. Bada, G. (2017) reported that on $10^{\text {th }}$ October, 2017, a Nigerian Senators in person of Sen. Baba Kaka Garbai (APC Borno Central) have raised a motion against the menace of pharmaceutical drug abuse with preference to codeine cough syrup. The Senator condemned the consumption of codeine syrup and cannabis by youths in the Northern Nigerian. According to the Senator, the unnecessary consumption of codeine cough syrup and other related prescriptive drug have become as termed, " the new corona virus ravaging both men and women in the North. Part of Nigeria, particularly the youth below the aged of 16 to 18 years old. In the same vein, NDLEA said, the North has consistently had the highest number of drug related arrests in recent years, with 2,205 cases in 2015. In another development, Alake, M. (2018) as in Stephanie Hegarty article that vigilante fighter, those displaced by the war, and other individuals are the hooked of consuming Tramadol in Maiduguri, Borno State. The wave is crippling Borno State where thousands of people are addicted to Tramadol. The reports show that one in every three youths is addicted to one type of drug or the other in Maiduguri (NDLEA, 2018).

Drug abuse is rapidly becoming a attracted business among youth in Maiduguri as they have been busy always making the drug business in the broad daylight at almost all the wards in Maiduguri Metropolitan. However, besides, the Government efforts to curb the problems of drug abuse, yet the disturbing challenge are the uncontrollable commitment of the youths towards abusing drugs. Unfortunately, the youths are either underrates the consequences of the drug abuse or unaware of the dangers involve in drug abuse. It is in fact obvious that drugs abuse could lead to complicated illness and sudden death. It is against this backdrop; the researchers tend to find out the causes and what influencing the youths to indulge drug abuse. This paper also discusses the negative consequences of drug abuse on our youths and thereby giving strategies and suggestions on how best to minimize the drug abuse phenomena among youths in Maiduguri, Borno State and the nation at large.

\section{$>$ Objectives;}

- To identify the factors motivating youths into substance addiction in Maiduguri.

- To determine the implications of substance abuse on youth.

- Assess the youths' attitudes knowledge and perception on abuse of drugs.

- Suggest the best way forward to minimize the menace of drugs abuse among youths.

\section{$>$ Research questions;}

- What are the factors motivating youths into substances addiction?

- What are the common effects of drug abuse among youths in Maiduguri, Borno State?

- What are the most common substance addictions by youths in Maiduguri, Borno State?

- What is the level of knowledge and perception of youths toward abuse of drugs?

- In what ways can substance abuse can be produced to the bearest minimum among youths in Maiduguri, Borno State.

\section{$>$ Hypotheses}

That joblessness, peer group, broken home, poverty and access to the drugs and lack of awareness on the dangers of abusing drugs are the principal causes that influencing the youths into drug or substance abuse in Maiduguri, Borno State. 


\section{METHODOLOGY}

A descriptive survey method was utilized to obtain accurate information on the roots of substances addiction among youths in Maiduguri, Borno State. A Focus Group Discussion (FGD) was adopted to obtain the data using interview, observation, and questionnaire. The respondents were selected in various locations of Maiduguri Metropolitan (MMC). A sample of (150) (addicts) respondents were used in ten wards within Maiduguri Metropolis. A statistical method of frequency distribution and percentages backing with Chi-square was used to distinguish the responses of the respondents. Relevant empirical studies and literature on the subjects under scrutiny were thoroughly examined and found relevant cases and information. The study was conducted without regards to any demographic consideration.

\section{DISCUSSION}

The findings of the research questions is in consistent and conformity with the research objectives and hypotheses and were answered by various respondents and their responses supported the research hypotheses that joblessness, broken home, intimate friends influence, poor knowledge on the hazards or danger of abusing the drugs and access to the drugs among other things are the key factors influencing adolescents into drugs addiction in Maiduguri, Borno State. Majority of the respondents from all the selected areas had the same responses in respect of what influenced them to engage in abusing substances. It is therefore, glaring that established facts that joblessness and peer group influence as well as poor knowledge of the negative implications of the substance abuse on human being and other related factors playing a significant role in involvement of youths to drug abusing phenomena (Field Survey, 2019). Nigeria is also one of the Nations who are contributing its shares to the cultivation, manufacturing, transits and abuse of wide range of drugs. The youth are the cornerstone of Nigeria future development and regrettably most of the youth abusing substances of all sort. (Abdullahi, 1991). Backing the study hypotheses, Abdulmalik et al., (2008) is of the opinion that joblessness is one of the key factors attracting the youths to abuse drugs. In addition,Muslim Right Concern MURIC, (2018) reported that the jobless Almajiris are also abusing drugs, and thereby use them by drugs couriers to sell the illicit drugs at their own peril. More than 50 jobless youths (Almajiris) were arrested by NDLEA in 2018, and confirmed to have being in the substances selling business activities (Adewale, 2019). It is however fact that absence of the either parents making the children's vulnerable to drug addiction. This is probably true due to parents absencenteeism sometimes undermine the proper socialisation of the children (Fine \& Kleinman, 1979). In the findings of Huba, Wingard and Bentler, (1979) opines that most populated and slum areas are also a drugs core for drug addicts, particularly for families in which parents are so obsessed and fatigue by their survival struggles, that they have small or no time and patience to take care of the children' s problems (Huba, Wingard, \& Bentler, 1979:
34). In some families, children may be asked to hawk all types of goods on the streets to generate income to the family' $s$ and later exposed the immoral habits and all vices associated with street lives including drug abuse. Therefore, environmental factor is also the determining the youths vulnerability to certain act capable of doom their future (Cohen, 1998; Ikoh et al., 2019). Empirical findings show that children who use drugs illicitly often come from families where one or most of the parenting is drugs abuser (Gorsuch \& Butler, 1976). Another study indicates that besides parental influence on youth' $s$ abuse of substance, poor neighbourhoods and intimate friends control also exert a positive effect on drug abuse (Brunswick and Boyle, 1979). On the contrary, Broom and Selznick (2000) itemized key motivating factors aiding toward drug abuse to include the need for ranking trinket seeking, curiosity or experimentation, relief from weariness, and a special remuneration to conformity (Lettieri, 2005; Ikoh, et al. 2019). Available evidence from the work of Hawkins (2009) has reflected the study hypotheses that make a child more likely to use and abuse drugs. These includes: a family history of substance abuse, parental drug use, an unorganized family with poor discipline in turn adulterated children' $s$ habit to indulge in fighting, stealing, etc,. Others are little commitment to school or education (formal or informal), lack of social bonding (a feeling of not belonging anywhere), friends who are using drugs, a favourable attitude toward drug use, and early first use of drug joblessness and frustrations among others (Adenaike et al., 2014: 87). Similarly, Glenn, (2009) mentioned some features that may lead to drug use and abuse. According to him children who use drugs tend to have anxiety, greediness, state of despair, uncontrolled ,poor public expression, loneliness ,misapprehension, inability to take decision, unwilling to accept responsibility, poor judgement among others . Nortey, et al., (2009) also added that most students are influenced by their bad friends to take drugs to read and pass examination. Other factors are boredom, experimentation, anxiety and bravo respectively. University of Michigan (2011) study findings revealed that legitimizing the smoking of Indian hemp, known as Marijuana in some American States making it accessible to all and a sundry particularly among the tertiary institutions' students to the extent that the abuse of the Marijuana index reportedly goes high ever in the decades. Another evidenced from the study in Maiduguri, the Borno State capital revealed that appreciable number of youths and the elderly persons, married and bachelors are abusing various substances like Tramol, Marijuana, Cocaine, Magadon, Janki, Suck and die, Alcohol, Cannabis, Rohypinol, Diazapam, Nicortin, Nitrazepam, Benzhexol, Codeine, others are herbs mixture drugs, ordinary snub, Matala, Rumb, Gulub, Burkutu and others related substances extracted from leaves of trees/herbal. These substances according to this study are being used and abuse both young and the old people with a view to calming their mind or tension and help enhance their sexual performance (Field Survey, 2019). According to Magaji, A.A. (2019) most peoples now a days irrespective of age, nor sex abusing all sort of stimulants and narcotic substances for the purpose of altering their mood. Recent research 
indicates that substance addiction challenges are too alarming among adolescents in Nigeria. (Igwe et al., 2009). Another Study shows that abuse of psychoactive drug is a common challenge among the adolescents especially for socially acceptable drugs such as alcohol and cigarettes. Alcohol and cigarettes are termed as gateway drugs because they are the ones that welcome the adolescents into drug abuse. These drugs are mostly abused because they are readily available (Okoza et al., 2009). In another development, studies showed that a parent has a role to play with regard to how best to curb the challenges of drug use and addiction among adolescent. Hawkings, et al., (1997) has reflected the study hypotheses that adolescents are prone to synthetic abuse where he/she has a family substance addiction history. (Namadi, M. 2016). In the other hand, children childhood socialization determining the vulnerability of the children' $s$ toward drug use and abuse. (Brook, Gordon, et al., 1990; Namadi, 2016). On the other hand, Ethel, (1998) said that most peoples conditioned themselves for taking substance through experimentation to know the real feeling and reaction of the drugs without considering the consequences. Ethel draws doubt whether bulk of the peoples abusing drugs to enjoy the stimulant effects. (Eric, P. 2017). Furthermore, Prim, (1991) assumes that jobless youth with abject poverty living in slum area is vulnerable to drug use and addiction.(Eric, P. 2017). Other studies showed that social media demonstration of the positive effects of the substance addiction is heavily contributing to substance abuse among youth. Therefore, parents must wake up and rise up to the expectation and control the unnecessary television programmes their kids watch, (Adenaike, et al., 2014) scholarly argues that the motive influencing youths or people to abuse substances is relative to individual, geographical location and time (Namadi, 2016).

\section{> Theoretical Perspectives on Drug Abuse}

The theoretical models of drug abuse shows that many people truly depend on certain substances for their survival as a result of a number of factors. The principal emphasis of the models is that people have their individual reasons for depending on one form of drug or the other. These purpose is put forward by Eze and Omeje (1998) as cited in the work of (Oluremi, 2012; and Mamman, et al., 2014: 6) explained using the following models, Personality theory of drug abuse; Generic theory of drug abuse; Socio-Cultural theory of drug abuse; and Social Learning Theory of Drug Addiction; Availability and Proneness theory o illicit Drug Addiction; Enviromental factors Theory of Drug Addiction; Personality Theory of Drug Addiction.

\section{$>$ Generic Model on Drug Addiction}

According to the model, peoples who have a family history of substance abused or alcoholism has a higher risk of developing drug abuse problems. The approach maintains that people who are genetically predisposed to alcoholism or substance abused have a higher risk of developing any substance use disorder. The approach further added although people can inherit alcoholic tendencies the development of an alcohol use disorder is also dependent on social and milieu factors. Some who have inherited genes making them susceptible drinkers/abusers or never take the drink in their life. The genes in person DNA that may amplify the risk of developing an alcohol use disorder. Certain combinations of genes have a substance abused (www.alcoholrehab.com, 2018-2019).

Substance abused is a diverse set of some common diseases that are some extend tied together by some shamed genetic and environmental factors. It is a chronic relapsing psychiatric disorders characterized by the compulsive and decontrolled use of a drug or activity with maladaptive \& destructive outcome (Bevilecgua and Goldman, 2009).

\section{$>$ Socio-Cultural Theory of Drug Addiction}

This model is assumes that drug abuse is relative term, depending on how the individual and community defined the drugs. However, what is perceived as illicit drugs or addiction in one community might be opposite in another society. For examples, there are communities and tribes who are using alcohol and related substances as legal and part of their traditional rites, while in other communities' consumption of alcohol and marijuana is forbidden.( Bandura 1986;Fareo, 2012:343)

\section{Social Learning Model on Drug Abuse}

This approach is believed that abduction is a learned habit. In other words, people learn behaviour of others due to prolong content interaction and intensive observation of others action, when performing it. Therefore, it is glaring to demonstrate that peoples fall into substance use and abuse through modelling for learned. For instance, if an individual grows up in a domain where others appears to be remunerated for substance abused, there will be strong stimulus to duplicate the conduct or habit. It is now evident to prove that people learn to engage in substance abused through prolong observation of others behaviour. (Givazollas, 2014: Tom Horvalh et al (1995-2020).

\section{- Availability and Proneness Model of Illicit Drug Abuse}

Reginald G. \& Smart (2019). The availability and Proneness model of drug abuse assumes that people begin abusing drugs mostly when the vulnerable individual is exposed to a high level of drugs accessibility and availability. According to Reginald and Smart (2019) availability and proneness are the twin ingredient mingled together to create desire to the drug use and thereby addiction. Therefore, proliferation and prevalent of the drugs within the individual milieu addiction with psychological proneness of the person could aid to establish excessive desire in the minds of the individual to experiment the substance available and leading to addiction (Reginald and Smart). 


\section{Environmental Factors of Drug Addiction}

Childhood life interactions and socialization are most often determining the children future direction. Therefore, the home in which the child growing may have a strong influence on his or her use of drug. Children who grow up in a broken home are likely to become addicted later in life. Another factor motivating the youth into drug activities is home environment where the drugs business is rampant can influence the youth into drug use and abuse. Similarly, in environments, communities or societies where drugs are seen as acceptable as ordinary paracetamol are likely influence the youth to drug use and abuse (www.addictioncompuses.com)

\section{$>$ Personality Model of Substance Abuse}

This model explanation is central to certain predisposition people have has that could motivate them dual to indulge in achieving substance use and abuse. Such features are: endurance to indignation, lack of self control, lack of self control, lack of coping mechanism, over relay on process, lack of confidence and perfecting toward self. According to personality model, peoples who posses these caricatures are prone to drug substance use and abuse.(Terracciano,A,et

al,2008;Rettner,R,2014;Rascanu,R,2005Clen,F ,et al,2019)

\section{Causes of Substance Use and Addiction}

There are many factors culpable for substances abuse, though the below are some of the motivating factors dragging the youth into substance addiction in society with particular reference to Nigeria context as cited in the works of (Mamman., Othman \& Lian, 2004; Haladu, 2003; Fareo, 2012; Mamman, et al., 2014; Yusuf, Gazali \& Abdullahi, 2017; Oluremi, 2012; Dasalu, et al., 2010; Ajibula, 2011; Henry, Smith, \& Caldwell, 2006); Igwe et al., 2009, Abudu, 2008); Oluremi, 2012; Desalu. et. al., 2010; Ajibulu, 2011; Henry, Smith \& Caldwell, 2006).

\section{$>$ Intimate Friend Influence}

Peers can influence their friends in destructive path. It is obvious that teens have a relatively cogent influence over on one another' $s$ behaviour and they are more likely take the risks in group peer pressure from children, friends in school can have a high effect on decision they male. Bad friends play a significant role in determining your child makes decision. For examples, many youth are being influenced by bad friends into marijuana business and other related antisocial phenomena. Nova Recovery Centre (2018) Peer pressure and Drug Abuse (www. novarecoverycentre.com).

\section{$>$ Desire for new experiences}

Many youth nowadays are curious of experiment every drug without knowing the negative impact of the substances toward their health (NIDA, 2014). On the other hand, Kindra (2019/20200 listed eleven (11) reasons why teenagers experimenting drugs.

\section{$>$ Poor Monitoring and Care}

Some parents are ignorant of their duties or functions towards their children. Proper upbringing of the children is one of the fundamental and inevitable tasks every parent is expected to do. For any society to achieve it set goals and objectives, the future leaders should have the normal socialization at the childhood level. However, for that to be achieved parent should sacrifice their time monitoring and assessing the movements of their children with a view to put them to the right path. When the parents does not give the deserve upbringing, the children may influenced by bad friends and thereby join gangs group and introduce them to drug related activities, hence lacking all the moral guidance at the childhood stage.

\section{$>$ Sex Performance and Relaxation}

Many people between the ages of 18 and above nowadays are addictive to various sex enhancement drugs with a view to satisfy and impress their sexual partner, while others abusing stimulant and narcotic drugs to relax and calm their frustration. The sex enhancement drugs include Vega tablet, anafranil and Vega spray and related enhancement drugs. However valium and related sleeping drugs are abusing for relaxation and calmness of minds, yet the continue abuse of the drugs for increasing sexual strength making them addictive

\section{The media favourable propaganda and accessibility of the drugs \\ Media power and accessibility to the substance} making it possible for drugs vulnerable to demonstrate enthusiasts and willing to establish ground on the activities of substance to a sanction \& abuse. Many adolescents were reported to have dragged into the substance abuse due to the behaviour media advertisement. Allowing government doing it best to minimize the rate of the drug abuse among youths yet all effort prove abortive.

\section{$>$ Poor Financial Muscles of the Family}

Failure of the children' $s$ family heads to fulfil the required responsibility of support; as the saying goes " an empty mind is a devil's workshop" . The education of their wards and provision for them all the essential needs could breed frustrations among the children' $s$ and thereby pave them a way to engage in any activities to get a source of income for themselves.

\section{$>$ Joblessness}

Beside all efforts to control the substance addiction among adolescents in society. Unfortunately the rates of unemployed are too alarming that something need to be done urgently to arrest the challenges before it too late. Most of the drug peddlers are targeting most vulnerable youths to serve as their drugs selling agents in various communities, hence the youth are jobless .This situation influencing the youth thinking faculty and thereby start abusing the substances of all sort, while selling the drugs 


\section{> Pathological family background}

Most of those abusing substance were a victim of genetics composition which predisposed to engage in the activities of substance addiction.However, other sensitive factors include, broken homes, and socialization etc.

\section{$>$ Lack of sufficient awareness of the negative effects of substance addiction on health}

It is glaring from several study that poor sensitization and sufficient knowledge of the drugs accessing making them vulnerable to engage in substances abuse. (Mamman, et,al., 2014: 6-7).

\section{Real Reasons Why Adolescents Experiment Substances}

According to AACES and Kendra' s,(2018).the followings are the 11 real reasons why adolescents experiment substances

\section{- Boredom}

It is refer to a substance feeling of being weariness or irksomeness in the engage activities of people consuming substance in order to alleviate the development irksomeness in their everyday activities or engagements. For examples, people in rehabilitation treatments for drug addiction are relapse back into the substance abuse. .(cited in the work of AACES and Kindra.S,,2018)

\section{- A Bonding Experience}

The desire and efforts of some adolescent to establish strong cohesion with the new peoples most often drag them into substance abuse. For example, if the new people' $s$ helshe met are substance addicts' habits. It is difficult to interact with them unless the new member also abusing substance like them, otherwise the relationship may not last and distant themselves from the new member. However, ability of the new entrance to accept their subculture act could lead the new member to open door for substance addiction.(cited in the work of AACES and Kindra.S,2018)

\section{- Depression}

Studies available showed that most of the adolescents start abusing drugs of all sort particularly the stimulant substance in order to calm their frustration experiencing. The use and abuse of substance embrace to forget their depressed feelings continuous to influence their minds to repeatedly abuse and thereby become addictive like all other addicts.(cited in the work of AACES and Kindra.S,2018)

\section{- Curiosity}

Effort to test one substance or the other at the adolescent period is inevitable practice among youth between the aged of 15- 18 years old. These are strong motive in the adolescent mind to experience any drugs without regards to it negative effects. When the testing of the substance suits their journey, they would continue to use it and becoming mature addicts (cited in the work of AACES and Kindra.S,2018)

\section{- Weight Loss}

Aspiration of female adolescents to make their body physically look slim to attract male has been a serious phenomena among the western world female students most of whom are using combination of several substance with a view to slim their physical structure to suit the modern world journey. Unfortunately, the substances using has strong effects on their health and subsequently, render them addictive.(cited in the work of AACES and Kindra.S,,2018)

\section{- Stress}

Many people now a day' $\mathrm{s}$ tasking substance to get relief from stress experienced as a result of roles. Overloaded engagements .For example, a student who experienced examination scheduled activities may resort to use substance to alleviate the degree of the stressed and thereby leading to drug addiction.(cited in the work of AACES and Kindra.S,,2018)

\section{- Low Self-Esteem}

A love to gain popularity and respect among adolescents of between the aged of 14-18 years old is something unique. These will build instinct in their mind to take substance to achieve the desire self respect and popularity which eventually becoming addict and end up self esteem less.(cited in the work of AACES and Kindra.S,,2018)

\section{- Peer Pressures}

It is known fact that adolescents have strong desire to participate actively in any activities with out knowing the negative implications. Peers are oftentimes wise enough to influence friends to any destructive activities due to their prolong contact and interaction of one another. For example, adolescents who are feeble minded are most vulnerable to introduce them to any form of anti social acts without questioning the impact. It is glaring that most of the juveniles delinquent in our community were victims of bad friends (cited in the work of AACES and Kindra.S,2018)

\section{- Enhanced Experiences}

Oftentimes adolescents are abusing substances of all sorts make them feel agile and energetic to carryout assignments efficiently and effectively. For example, abusing sex enhancement drugs is common now days among peoples with a view to impress their partner and feel high (cited in the work of AACES and Kindra.S, 2018)

\section{- Now or Never}

Adolescents feel they are due for engaging in any activities during their transition period before graduating to the adulthood. Often times, the adolescents are vulnerable of taken self destructive decision and action leading them into substance addiction.(cited in the work of AACES and Kindra.S,2018) 


\section{- Genetics}

Many scholars are of the believed that people who has family substance addiction history could inherent the substances abuses act. In view of this any adolescent who belong to addictive family is likely to becoming drug addict (cited in the work of AACES and Kindra.S, 2018)

\section{> Top 10 Most Abused Drugs}

Top 10 must abused substance, as approvingly cited in the works of Cabin.C,M (2012),,NAFDAC (2000), Adenaike et, al., (2014: 81) ; (Haladu, 2003; Fareo, 2012: 342; Yusuf, Gazali \& Abdullahi, 2017); Namadi, 2016: 196; Agwubike, 1998; Miller, 2000; Adenike, et al., 2014) are classified as follows:-

\section{- Tobacco/Nicotine:-}

The tobacco/ nicotine are the most substantial addiction substance globally became a pandemic undermining the health status of millions of peoples across the world. Recent business statistics report indicates that peoples making millions of dollars on tobacco//nicotine business on daily basis and unfortunately the smokers of the tobacco/nicotine are considerably increasing beyond imagination. Despite the entire health hazard associated with smoking cigarettes, the number of the smokers is unprecedented that something needs to be done to curb the menace. Most of the drugs related cases recorded were emanated from tobacco smoking, killings millions of smokers annually. Tobacco smoking diseases including tuberculosis cancer etc.(Cabin.C,M,2012)

\section{- Alcohol}

The legality granted to alcohol from various societies is being abused by many without considering the negative implication to human health. Recent studies showed that millions of alcohol addicts are on hospital beds suffering from liver exhaustion, cirrhosis, brain confusion or damage and other alcohol illnesses. It is the legalization of the substances in many countries and communities fuelled the increasing numbers of the peoples consuming the alcohol thereby battling with it effects in long run.(Cabin.C,M,(2012)

\section{- Prescription}

Even though, using prescription substance is accepted every where but unfortunately many peoples capitalizing the legality to illegalize their consumption of the prescribed drugs to addiction.For examples, stimulants,depressants and opiates substances are the considerable drugs indiscriminately abuse without strict adhering to the physician prescriptions which in turn claims the lives of most addicts of these substances. (Cabin.C,M,(2012)

\section{- Non Prescription Medicine}

It has becoming a common attitude to many people' $\mathrm{s}$ around the world to use drugs without consulting relevant physician. These self- prescription phenomena have silently killed millions and rendered similar figures addictive. For examples ,peoples abusing the substances often times due to lack of strong policy of drugs regulations, accessibility to the substance and poor awareness of the danger of consuming among labourers and others who are doing hard labour to earn a daily cash. It is common amongst the non prescription drugs abusing, including pain reliever like paracetamol antibiotics and sexual enhancement substances. However, these peoples in long run graduating to most powerful substances like cocaine and related substance to subdue their anger and activate energy at their own peril.(Cabin.C,M,(2012)

\section{- Methamphetamine}

It is an uppermost potent substance with strong negative effects central to brain nervous system that could easily establish psychological problem with unique feelings of joyous. Methamphetamine is globally restricted substance with powerful common effects and not accessible to common man, yet the influential personalities have partial access to the drugs through illegal means. It could turn the users to addicts within a couples of weeks of experimented it. It is really illegal and dangerous drug and inaccessible in most countries of the world.(Cabin.C,M,(2012).

\section{- $M D M A / E c s t a s y$}

This substance is commonly accessible and available in almost all the countries. It is a drug with high content of stimulants and hallucinogenic effects use and abuse during festival, parties, clubs, and other related events. All with a view to alter their mood perception, increase energy and pleasure. Unfortunately high consumption of the substance could negatively affects the users, making him/her addict, memory problem, paranoia, difficulty sleeping, blurred vision, rapid heartbeat, always dehydrated among others.(Cabin.C,M,(2012)

\section{- Cocaine/Crack}

The cocaine and crack are most potential substances with equal addictive effects but not accessible like others drugs and globally pronounced as illegal substance with serious penalty. It has pose threat to many western world countries. Cocaine is a highly strong anti depressant powder with mental effects of loosing of contact with reality, coupled with potent feelings of joyous and agitation. (Cabin.C,M,(2012).

\section{- Heroin}

Heroin is a powerful analgesic substance available in most countries of the world, High consumption of heroin alters the physical structures and psychological brain of the abuser. (Cabin.C,M,(2012).

\section{- Steroids}

Anabolic steroids are either prescribed or illegally accessed by the person who wants to appear stronger and with aim of making him energetic and build muscles mass in a shortest possible period, with hope of increasing confidence and self esteem. Unfortunately, prolong use of steroids generates healthy hearts, lever damage, kidney failure, high blood pressure, leading to risk of stroke and heart attack. (Cabin.C,M,(2012) 


\section{- Inhalants}

This is commonly found and abuse that produce chemical vapours, when inhaled and result in mind altering effects. Unfortunately, abusing high dose can generate confusion and Delirium. Inhalants addicts most often experienced dizziness, drowsiness, slurred speech, general muscles flaws, and depressed reflexes among other things. These substances are tube solution, air cans for computers, petrol, gasoline etc. (Cabin.C,M,(2012).

\section{$>$ Available Signs of Understanding Peoples with Substance Abused Problems}

Brunilda.N, (2008), cited in the works of WebMD. (2018); Brunidal. N, (2018); AACR, Kindri. S, Thomas. S, (2019-2020); Maldonado. L, (2016) and Kindra. S, (2007) Mba (2008) as cited in Forea (2012), Yusuf et, al., (2017); Olawale (2018); (AHIP, 2001; Tracy, N. 2012); Fareo, (2012: 344) and Olawule( 2018) state the following signs of drug addiction often manifesting on the body chemistry of the addicts;

\section{Signs you may have a drug problem}

- You keep taking a drug after it's no longer needed for a health problem.

- You need more and more of a substance to get the same effects (called "tolerance"), and you can take more before you feel an effect.

- You feel strange when the drug wears off. You may be shaky, depressed, sick to your stomach, sweat, or have headaches. You may also be tired or not hungry. In severe cases, you could even be confused, have seizures, or run a fever.

- You can't stop yourself from using the drug, even if you want to. You are still using it even though it's making bad things happen in your life, like trouble with friends, family, work, or the law.

- You spend a lot of your time thinking about the drug: how to get more, when you'll take it, how good you feel, or how bad you feel afterward.

- You have a hard time giving yourself limits. You might say you'll only use "so much" but then can't stop and end up using twice that amount. Or you use it more often than you meant to.

- You've lost interest in things you once liked to do.

- You've begun having trouble doing normal daily things, like cooking or working.

- You drive or do other dangerous things (like use heavy machines) when you are on the drug.

- You borrow or steal money to pay for drugs.

- You hide the drug use or the effect it is having on you from others.

- You're having trouble getting along with co-workers, teachers, friends, or family members. They complain more about how you act or how you've changed.

- You sleep too much or too little, compared with how you used to. Or you eat a lot more or a lot less than before.

- You look different. You may have bloodshot eyes, bad breath, shakes or tremors, frequent bloody noses, or you may have gained or lost weight.
- You have a new set of friends with whom you do drugs and go to different places to use the drugs.

- You go to more than one doctor to get prescriptions for the same drug or problem.

- You look in other people's medicine cabinets for drugs to take.

- You take prescribed meds with alcohol or other drugs.

> Signs someone else is addicted:

- Changes in personality and behaviour like a lack of motivation, irritability, and agitation

- Bloodshot eyes and frequent bloody noses

- Shakes, tremors, or slurred speech

- Change in their daily routines

- Lack of concern for personal hygiene

- Unusual need for money; financial problems

- Changes in friends and activities

The 10 Most Common Signs of Drug Use and Addiction According to Kindra S, (2007), there are some signs that are common to many people who abuse substances, including the following:

- Intense cravings.

- Tolerance.

- Withdrawal symptoms.

- Physical dependence.

- Engaging in increasingly risky behaviors.

- Drug-seeking behaviors.

- Financial trouble related to drug use.

- Neglecting responsibilities.

- Developing unhealthy relationships with those who support addiction.

- Isolating behaviors.

Kindra S, (2007) further believe that people who are addicted to drugs are vulnerable to exhibit a few or all of the following signs and symptoms;

- Cravings. People suffering from addiction usually experience intense urges or cravings for the drug as their addiction develops. Cravings can be thought of as the conscious or unconscious experience of wanting to use a substance. 2 They are a central feature of addiction. (www.luxury.rehabs.com)

- Tolerance. Over time and with prolonged use, those who use drugs can build up tolerance to them, meaning they need more of a drug to achieve the desired effects.3 (www.luxury.rehabs.com)

- Withdrawal symptoms. Many drugs create withdrawal symptoms when those who use them attempt to stop abruptly or reduce their usage. The presence of a withdrawal syndrome and tolerance indicates that physiologic dependence on a substance is occurring.4 (www.luxury.rehabs.com)

- Physical dependence. Physical dependence on drugs can develop as individuals grow accustomed to the persistent presence and influence of the substance. The changes in physiology that accompany this process leave people feeling poorly or functioning sub- 
optimally when the drug is no longer in the system.5 (www.luxury.rehabs.com)

- Poor judgement. When an individual is addicted to drugs, he or she may do anything to obtain more, including risky behaviors such as stealing, lying, engaging in unsafe sexual activity, selling drugs, or crimes that could land the person in jail.6-8 (www.luxury.rehabs.com)

- Drug-seeking. People may spend excessive amounts of time and energy finding and getting their drug of choice. (www.luxury.rehabs.com)

- Financial trouble. Individuals using drugs may spend large and unexplained amounts of money, drain their bank accounts, and go outside their budgets in order to get the drug. This behavior can be a major red flag for addiction and has massive consequences. A recent survey of 341 Americans showed that $44 \%$ had a loved one with a substance use disorder, and of those with a substance use disorder, $48 \%$ drained savings or retirement accounts, $42 \%$ sold assets for cash, $11 \%$ filed for bankruptcy.9 (www.luxury.rehabs.com)

- Neglect responsibilities. When people choose using or getting the drug over meeting work or personal obligations, this is a classic sign of addiction. (www.luxury.rehabs.com)

- Developing unhealthy friendships. When people start using new substances, they may spend time with others who have similar habits. They may hang out with a new group of people who may encourage unhealthy habits; doing so makes them more likely to use for a longer time, especially if others in the group have a negative life outlook.10 (www.luxury.rehabs.com $)$

- Isolate. Alternatively, individuals may withdraw and isolate themselves, hiding their drug use from friends and family. Some reasons for this may include perceived stigma or increased depression, anxiety, or paranoia as a result of their drug addiction. (www.luxury.rehabs.com)

\section{> Conceptualization of Drug Use and Drug Addiction}

Drug is any synthetic substance people' s use irrespective to modify the function of their mood and behaviour. (Mahmud, et al., 2016: 14). Drug abuse is a use of drugs to the extent that it interferes with the health and social function of an individual (Abdullahi, 2009; Namadi, 2016: 196). Drug abuse is refers to as indiscriminate application of substance without physician prescription (Odejide, 1997). According to Robin, (1972) drug abuse implies the use of a given drug in excessive dose levels, over an unjustified period of time, or outside therapeutic indications (Yusuf, Gazali \& Abdullahi, 2017). The definition focuses on application of anti depressants substance to alter their psychological mood to achieve their immediate joyous goals, not knowing that the prolong addiction could undermine his/her future journey and subsequently affecting the health condition of the abuser. (Namadi, 2016: 196). Drug abuse can be further seen as the deliberate use of chemical substances for reasons other than intended medical purposes and which results in physical, mental, emotional or social impairment of the user. The abuse of legal drugs can happen when people use the drugs in a manner other than directed by the physician, manufacturer or purpose that are not legitimate (Olawale, 2018). Drug abuse refers to a hazardous use of stimulant substances to derive pleasure.the substances including, marijuana, LSD, alcohol and other related illicit drugs (WHO, 2019). Drug abuse is defined as the use of synthetical substance for intoxicating to source for pleasurable effect on the brain (Mandal, 2000-2019). Drug or substance abuse, according to Wikkipedia, (2019) refers to a patterned of use of a drug in which the user consumes the psychoactive chemical substances in amounts or with methods which are harmful to themselves or others. Similarly, Tracy, (2012) describes drug abuse as a mere increasing desire to obtain and use increasing amounts of one or more substances to the exclusion of everything. Drug abuse affects the body and mind of the user and often many of those around him/her. One specific effect of drug abuse is the creation of physical drug dependence; however, dependence on the drug is not required for drug use to be considered drug abuse (Tracy, N. 2012). The drugs commonly abuse by the youths in Maiduguri are made up of herbs mixtures, includes; Snubbed powder, Janki, Matala, Anguru, Kumb, Gulub, Abba Jaura, Chally, Colanut, Dan Cameru, coco extra, bitter cola, Rubber tube (solution) amongst others. These are the locally made drugs available consumes, beside the other re- known drugs, though it like any other drugs given the abusers extraordinary stimulant feelings and strength to accomplish all intended task. The locally/herbal made drug is being consumed by all aged category almost most of aged category 26 and above irrespective of demographic affiliation (Field Survey, 2019).Any substance indiscriminately use by an individual without seeking the suggestion of health care personnel is considered as substance addiction. For example, paracetamol is often times use for an ordinary headache and body pains, but if an individual use it repeatedly as self medication without medical specialist consultation is termed as drug abused.(Amina, 2016; Yusuf, Gazali \& Abdullahi, 2017).

\section{CONCLUSION}

Based on the theoretical opinions used in the work and the empirical findings of the study, it is obvious to conclude that the abuse of drugs and other substances constitute a great problem affecting the person and the community at large. The problem is prevalent among the youths, and Maiduguri youths are also not exception of the phenomena (Field Survey, 2019). This paper revealed that the bulk of the youths abusing the substances interviewed were ignorant of the hazards associated with drugs abuse. Besides the accessible drugs such as marijuana (wee wee), exzol, D.5, valium, tramol, codeine, cocaine, alcohol and related drugs. The youths and other peoples outside the drugs abused subculture also abusing locally manufactured or herbal mixtured drugs including Matala, Kumb, Gulub, Janki, Dan-Cameru, Chally, Rubbertube, Coco extra, bitter cola among others. All abuse with a view to give them energy and alter their mood for pleasure (Field Survey, 2019). The study also shows that majority of those 
interviewed were engaged in the doing abuse activities as a results of family broken down, frustration and joblessness, poverty, environmental factor, poor parental supervision, peer group influence, Boko Haram insurgency factor, curiosity and experimentation as well as access to the drugs among others are the principal factors motivating the addicts. However, effort to fight the proliferation of the substance addiction among the youth demonstrated the need to take collective action at all level to minimize the problems as Government alone cannot solve the problems within a shortest possible time. The study also commended the efforts of Borno State Government, under the leadership of Governor Baba Gana Umara Zulum banning political thugs, and released five hundred million as social support to four thousand jobless youths spread within the fifteen (15) wards of Maiduguri Metropolitan of Borno State. It is however, obvious in the study findings that bulk of the substance abusers are unemployed and one third of them also embraced political thuggery as their way of survival or source of income (Field Survey, 2019; Daily Trust, Tuesday, August, $6^{\text {th }}$ 2019: P7)

\section{RECOMMENDATIONS}

The following recommendations were made so as to tackle the phenomena of drug addiction in Maiduguri, Borno State and Nigeria at large.

$>$ That intensive parental supervision is highly needed. As some parents have less time to coordinate and monitor the movement of their worth or have time to interacts due to nature of their work or negligence. Therefore, active supervision of parents is highly recommended.

$>$ Sociologist, social workers and qualified medical counsellor unit should be established at all community with mandate of giving advises, suggestion and guidance to youths around regarding the effect of drug abuse.

$>$ Parents and guidance should keep monitoring and know the calibre of friends of their children in order to avoid peers influence that could drag their children into drug abuse.

$>$ Community leaders should be given a mandate to control the proliferations of locally herbs mixture drugs consume by both the young and adults of both sex for increasing strength and enhance sexual pleasure.

$>$ Parents and guidance should not pressurize their children to pass examination with high grades, as this pressure could lead them to use drugs to achieve the purpose and subsequently drag them into drug abuse.

$>$ Imams and Pastors have a significant role to play in mosques and churches to discourage with their faithful followers against drug use and other form of abuses.

$>$ Government and NGO' s should organize workshop, seminar, or conference at regularly basis for parents and youths on the hazards of substance abuse on human health.

$>$ Prevention education and peer-based programme is also needed to be introduced in the communities. Since most of those interviewed claims that the motive for using drug is as a result of the influence of peers (friends), it is therefore, necessary to develop some peer support program to aid those experimenting with drugs to avoid further use.

$>$ NDLEA in collaboration with media house should join hands and embark on intensive campaigns against drug misuse and abate so as to have a substance abuse free community. This paper shows that majority of the abusers from all selected areas were ignorant of the dangers of drug abuse.

$>$ There is a need to design and develop a curriculum on drug abuse sensitization education at all schools level, in order to instil in them the dangers of substances abuse on their health.

$>$ Government at all levels and well to do individuals should as a matter of urgency redouble their efforts and create more job opportunities to our teaming jobless youths in order to minimize the unnecessary roaming of jobless youths in our streets.

$>$ There is need to balance the socio-economic status of all classes or citizens, as the findings reveals that some of that abusers felt discriminated and their involvement in the drug related activities were influenced by their poverty states and thereby frustrated and recruited themselves as distributor of marijuana etc.

\section{REFERENCES}

[1]. Abdullahi, Z. (2009). Drug abuse among Adolescents: Strategies for School Counselling. The Nigeria Society of Educational Psychologists, Jos, Nigeria. Pp.131136.

[2]. ACES and Kindra (2018) Eleven Real Reasons why Adolescents Experiment substances. www.drugabuse.com. All Rights Reseerved,2020..

[3]. American Addiction Centres Editorial Staff (2020). www.drugabuse.com/recoverybrands, LL/AAC, Inc. 2020. All Rights Reserved.

[4]. AACES, Kindri, S. \& Thomas.S, (2019-2020) Symptoms and Signs of Substance Abuse;Recognizing the signs of substance abuse. Cited in American Addiction Centres Resources.www.drugabuse.com.

[5]. Abdullahi, Z. (2009). Drug abuse among youths: Strategies for School Counselling. The Nigeria Society of Education Psychologists, Nigeria. Pp.131-136.

[6]. Abdulmalik, J., et al., (2008). Psychoactive substance use among children in informal religious schools (Almajiris) in Northern Nigeria. Mental Health, Religion \& Culture, 12, 527-542.

[7]. Abudu, R.V. (2008). Young people and Drugs Abuse: Biennial International Conference on Alcohol, Drugs and Society in Africa, Abuja, Nigeria. Between $23^{\text {rd }} \&$ $25^{\text {th }}$.

[8]. Adejide, A.O. (1997). Drug abuse and drug trafficking in Nigeria: An overview paper presented at the Nigeria Training Course on Drug Abuse, University of Benin, Nigeria. Pp.1-20.

[9]. Adenaike, A.S., et al., (2014: 87). Menace of Drug Abuse on Youth Development and Academic Performance: Evidence from Nigeria. Ago-Inoye Journal of Social and Behavioral Science. Vol.3, No.2, 2014. ISSN: 0795-9782. 
[10]. Adewale, M. (2018). North's Six Million Almajiris Potential Security threat to Nigeria. The Guardian. 5, $10-11$. July, $16^{\text {th }} 2018$.

[11]. Adolescents Health Information Project (AHIP 2001). Drug Abuse, Unpublished Pamphlet, Kano: AHIP Centres

[12]. Ajibulu, E. (2011). Eradicating Drug Abuse in Nigeria. How feasible? http://www.modernghanu.com/news/3375201/eradicat ing-drug-abuse-in-nigeria-how-feasible.html. Accessed Sept. $26^{\text {th }} 2019$.

[13]. Bada, G. (2017). The rise against the menace of drug abuse amongst youths. www.pulse.ng/news/local/codeine/rise-against-themenace-of-drug-among-youth. Accessed $10^{\text {th }}$ Oct. 2017.

[14]. Bolaji, K. (2018). Effects of substance abuse on Ilorin Youths. www.researchgate.net//publication/3236228786. Accessed Oct. $8^{\text {th }} 2019$.

[15]. Boys, A. et al., (1999). Substance use among young people: The Relationship Between perceived functions and behavioural intentions. Addictions, 94, 10431050 .

[16]. Brook, J.S., Brook, D.W., Gordon, A.S. (1990). The Psychosocial Etiology of Adolescent Drug use. A Family International Approach. Genesregenpsychol.monogram: 116(2), 111-267.

[17]. Broom, L., Selzmek, P. (2002). Sociology ( $7^{\text {th }}$ ed.). New York, NY: Harper \& Row.

[18]. Brunswick, A.F., Boyle, J.M. (1979). Patterns of drug involvement: Developmental \& Secular influences on age at initiation. Youth \& Society. 11, 139-162.

[19]. Buff, rehab (2018), Common Drugs of Abuse-Types of Addiction. www.buffsrehab.com. 2550 Lodge, Road SW., Sherrods Ville, Ohio 44675 Accessed 2205-2020, 12:45Pm

[20]. Brunilda N, (2018) Signs of Drug Addiction. WebMD, LLC. All Rights reserved, 2020

[21]. Clien, F. et al., (2019). Personality Model: Examining the relation of personality factors ton substance use disorder by explanatory them response modelling of DSM-5 symptoms. Https://journals.plos.org.

[22]. Cabin.C.M,(2012), 10 Most Abused Drugs. www.thecabinchiangmail.com. Accessed,MAY,2020

[23]. Cohen, S. (1998). The drug dilemma. New York, NY: McGraw Hill.

[24]. Dailytrust (2019: 7). Zulum bans political thugs, launches N500m as Social Support for 4,000 Jobless Youths. Eye on Borno. Dailytrust of Tuesday, August 6, 2019.

[25]. Desalu, O.O. et al., (2010). Smokeless Tobacco use in adult Nigeria population. Journal of Clinical Practice. Vol.13(4). Pp.382-387.

[26]. Drug effects on behaviour. Gateway foundation effects of drug abuse fact 22. www.samphsa.gov/atod.2015.Accessed,May, 2020
[27]. Effects of Drug Abuse Addiction. Addiction and Negative Effects of Drug Abuse on the Human Body and Brain. Gatewayfoundation.org. Accessed 28/05/2020.

[28]. Eric, P. (2017). Socio-economic effects of Drug Abuse among Nigerian Youths. CSC Canada Canadian Social Science. Vol. 13, No.1, 2017. Pp. 4953. ISSN-1923-6697. Published outline in $26^{\text {th }}$ January, 2017.

[29]. Eze, J.E. and Omeze (1999). Fundamentals of Substance Abuse. Enugu. Sneap Press Ltd.

[30]. Fareo, D.O. (2019: 343). Drug Abuse among Nigerian Adolescents Strategies for counselling.

[31]. The Journal of International Social Research. Vol.5. Issue: 20 (2012). www.sosyaclaratirmalar.com ISSN1307-9581.

[32]. Field Survey (2019). Drug Abuse among Youths in Maiduguri, Metropolis, of Borno State. A Study conducted on effects of drug abuse among youths spread within the (15) Wards of the Maiduguri Metropolis. Oct. 2019.

[33]. Fine, C.A., Kleinman, S. (1979). Rethinking Subculture: An interactionist analysis. American Journal of Sociology. 85(1), 1-20.

[34]. Giovazollas, I. (2014). Social Learning Conceptualisation for Substance Abuse: Implication for human health. Department of Psychology, University of Crete, Rethymno, Greece. www.ejco.p.psychopen.edu. $21^{s t}$ May, 2020.

[35]. Gorsuch, R.L., Buttler, M. (1976). Initial drug abuse: A review of predisposing social psychological factors. Psychological bulletin. 83, 120-137.

[36]. Horvath, T. et al., (2020). Learning theory of addiction and recovery implications. Centre site, $L L C$, 1995-2020. www.centresite.net. Accessed 21 ${ }^{\text {st }}$, May, 2020.

[37]. Haladu, A.A. (2003). Outreach strategies for curbing drug abuse among out of school youth in Nigeria. $A$ challenge for Community Based Organization (CBO). www.eaournals.org/www.researchgate.net.pub. Accessed $28^{\text {th }}$ Oct. 2019

[38]. Hawkins, J.D. et al., (1992). Riskand protective factors for Alcohol and other drug problems in Adolescence and Early Adulthood: Implications for Substance Abuse Prevention. Psychol-Bull; 112:64105.

[39]. Henry, K.L., Smith, A.E., Caldwell, L.L. (2007). Deterioration of academic achievement and marijuana use onset among rural adolescents. Journal of Health Education Research. Vol.22(3): 372-389.

[40]. Huda, G.J,, Wingard, J.A., Bentler, P.M. (1979). Adolescent drug use and peer and adult interaction patterns. Journal of Consulting and Clinical Psychology. 47, 265-276.

[41]. Ibrahim, H.A. et al., (2016). Effect of drug abuse among youth and its impact on learning (JOSR). Journal of Pharmacy and Biological Sciences (IOSRJPBS). Vol.11, Issue, 1 ver. III. Jan-Feb, 2016) Pp1417. ISSN: 2278-3008. P-ISSN: 2319-7676. 
[42]. Igwe, W.C. et al., (2009). Socio-demographic correlates of psycho-active substance abuse among Secondary School Students in Enugu, Nigeria. European Journal of Social Science, 12(2). 277-283.

[43]. Igwubike, E.O. et al., (2000). The effects of caffeine (coffee) on psychophysiological variables of selected University athletes. Benin Journal of Educational Studies; $12 \& 13$ (1\&2): 212-9.

[44]. Ikoh, M.U. et al., (2019). Factors affecting entry into drug abuse among youth in Lafia Metropolis: Implication on security. Journal of Sagepublication. Vol.9, No.1, January, $17^{\text {th }} 2019$. Accessed $15^{\text {th }}$ Oct. 2019.

[45]. INCB, Report (2013). Economic Consequences of Drug Abuse. UN treaty series, Vol.520, No.7515.

[46]. INCIR (2016). Borno Battles Drug Abuse in Displaced Persons Camps. www.icrRNigeria.com. Accessed $18^{\text {th }}$ Oct. 2019.

[47]. Kindra. S, (2007) The 10 Most Common Signs of Drug Use and Addiction. www.luxury.rehabs.com Access, 29 ${ }^{\text {th }}$ May, 2020

[48]. Johnson, L.D., O’ Malley, P.M. \& Benchman, J.D. (2000). The monitoring the future National Results on Adolescent Drug Use. Over of Key Findings 1999. US DHHS, National Institute on Drug Abuse, Rockville, N.D.

[49]. Lettieri, D.J. (ed.) (2006). Predicting adolescent drug abuse: A review of issues, methods and correlates. Rockville, MD: National Institute on Drug Abuse.

[50]. Magaji, A.A. (2019). Drug abuse among youth in Kebbi State, Nigeria. A Ph.D proposal Department of Sociology. Usman Danfodio University, Sokoto my.unizik.edu.ng. Accessed Oct. $16^{\text {th }} 2019$.

[51]. Mamman, H. et al., (2014). Adolescents and drugs abuse in Nigeria. Journal of Biology, Agriculture \& Healthcare. Vol.4, No.1. 2014. ISSN: 2224-3208 (paper) 2225-099X.

[52]. Mandal, A. (2000-2019). What is Drug Abuse? News.medicallife-science.net.AZO-network(20002019). Accessed 16 ${ }^{\text {th }}$ Oct. 2019.

[53]. Maldonado, L. (2016). Commonly Drug Abuse.An American Addiction Centres Resource.www.drugabuse.com

[54]. Mba, A.I. (2004). Essential Elements of 4-H Youth Development. National 4-H, Headquarters, (SREES UDSA. www.national4-hheadquarters.gov.libraryessential-element-sattelite.ppt.

[55]. Michigan, (2011-2012). National Survey on Drugs use and Health (NSDUH). www.samhsa.gov/data/report/michigan-2011-2012msdih.

[56]. Miller, B.J., (1974). Good health: Personal \& Community. $3^{\text {rd }}$ Ed. Philadelphia, Soundersmurin, C. (1973). Learning in Social Setting. Boston: Ally and Bacon, Inc.

[57]. Muslim Rights Concern (2018). Almajiri children, cultists, area boys \& drug addiction (being 2018 Children's Day Speech delivered by Prof. Ishaf Akintola, Director of MRC (www.muslimrightmuric.com Accessed, 21, 10, 2011).
[58]. Namadi, M.M. (2016). Drug abuse among adolescents in Kano Metropolis, Nigeria. Ilimi Journal of Arts \& Social Sciences. (IJASS). Vol.2, No.1. May-June, 2016. Accessed Sept. $20^{\text {th }} 2019$.

[59]. National Institute of Drug Abuse (2016) Commonly Abused Drugs charts. Https://www.drugabuse.gov/drugsabuse.com. Accesse d,21th,May,2020

[60]. National Drug Law Enforcement Agency (1997). Drug Data Collection and Research, Lagos: Drug Demand Reduction Unit, National Drug Law Enforcement Agency (NDLEAR: 1997).

[61]. National Drug Law Enforcement Agency (2018). Drug Free Club. www.ndlea.gov.ng/v1/?qcontent/drug/free/club. Accessed Sept. $22^{\text {nd }} 2019$.

[62]. Odejide, A. (1979). Alcohol use in sub-group literature Nigerian. African Journal of Psychiatric; Vol.5, 15-20.

[63]. Okonza, J. et al., (2009). Drug Abuse among students of Ambrose Alli. European Journal of Social Sciences. Vol.10 (1), Pp.85-92.

[64]. Olawale, S. (2018). Drug abuse in Nigeria: Causes, effects and solutions. Nigeriafinder.com Accessed $4^{\text {th }}$ Nov. 2019.

[65]. Omirin, O. (2018). UNICEF Joins Campaign against Borno Drug Abuse. A sensitization Workshop Organized by UNICEF in Maiduguri, Borno State, held on 2018 April 25. Accessed October, 10 2019 Daily Trust of October, $17^{\text {th }} 2019$.

[66]. Premiumtimes (2016). Borno laments worsening drug abuse amongst persons displaced by Boko Haram. www.premiumtimesng.com. Accessed, 26 $6^{\text {th }}$ Oct. 2016.

[67]. Robins, L.N. (1972). The National History of Drug Abuse. The theory on drug abuse. Washington DC.

[68]. Rettner, R. (2014). How personality increase risk of drug abuse. www.livescience.com. Future US, Inc, New York, NY10036.

[69]. Rascanu, R. (2005). The personality profile of the drugs addict. Europe' s Journal of Psychology. www.ejop.psychopen.au. ISSN Online: 1841-0413.

[70]. Reginald and Smart (2019) An availability and Proneness theory of illicit drug abuse: In theories on Drug Abuse: Selected Contemporary Perspective: NIDA Research Monograph 30 ${ }^{\text {th }}$ March, 1980. United State Government Printing Office, Washington, D.C, $\underline{20402}$ Retrieved from https://booksgoogle.com.https://archives.drugabuse.g ov.com Accessed, May, 2020

[71]. Stanton.p, \& Bruce, K. A,(2019)The Meaning of Addiction. Theories of Addiction

[72]. Lifeprocessprogram.1996-2020.https/www.peele.net. https:archives.drugabuse.gov.

[73]. Stanton. P, \& Alexandra. B.K, (2019). The Meaning of Addiction.3.Theories of Drugs addiction. Copyright, 1996-2020 Stanton Peele. https:/archives.drugabuse.gov. All Rights Reserved. Last Updated 12 December, 2019.

[74]. Signs and Symptoms of Substance Abuse.An American Council of Drug education/Phoenix House. Phoenixdrugabuse.org 2th,May2020. 
[75]. Smart RG, Murray GF.(2018) Narcotic drug abuse in 152 countries: Social and economic conditions as predictors. Int J Addict. 1985;20(5):737-49. doi: 10.3109/10826088509044293. [PubMed: 3876293].

[76]. Tracy, N. (2012). Effects of drug abuse, Healthy Place. www.healthyplace.com. Addressed, Oct. $25^{\text {th }}$ 2019.

[77]. Terracciano, A.; Lockenhoff, C.C.; Posta, T.P. Jr. (2008). Five factor model personality profiles of drugs - NCBI-HIH. https://www.ncbi.cim.nih.gov. BMC Psychiatric 2008, 8:22. Published online 2008, April, 11. DOI: 10:1186/1471-244x8-22. PMCID: FMC2373294. PMID: 18405382. Accessed 28/15/2020.

[78]. United Nations Office on Drugs \& Crime (2007). Drug Abuse and Drug Dependence Treatment Situation in Nigeria. UNODC, Data for the year 2007. www.unodc.org/docs/treatment/copro/web.Nigeriapdf.

[79]. Utomi, J.M. (2019). Drug Abuse \& Nigerian Youths. www.punchng.com Accessed, 16 ${ }^{\text {th }}$ April, 2019.

[80]. Yusuf, U.L., Gazali, W.A., Abdullahi, M. (2017). Drug Abuse among Youths in Nigeria. Implications to National Development. www.semanticscholar.org. Accessed Sept. $18^{\text {th }} 2019$. 